\title{
'NuMex Suave Red' and 'NuMex Suave Orange' Mild Capsicum chinense \\ Cultivars
}

Eric J. Votava ${ }^{1}$ and Paul W. Bosland ${ }^{2}$

Agronomy and Horticulture Department, New Mexico State University, Las Cruces, New Mexico 88003

Additional index words. Habanero, Scotch Bonnet, Capsicum chinense, capsaicinoids, HPLC, pungency

Received for publication 17 Dec. 2002. Accepted for publication30 June 2003. A contribution of the New MexicoAgricultural Experiment Station, New Mexcio State Univ., Las Cruces.

${ }^{1}$ Current address: DeRuiter Semillas Research, El Ejido, Spain.

${ }^{2}$ Regents professor to whom reprint requests should be addressed; e-mail pbosland@nmsu.edu.

The New Mexico State University Agricultural Experiment Station announces the release of 'NuMex Suave Red' and 'NuMex Suave Orange' open-pollinated Capsicum chinense Jacq. cultivars. The species $C$. chinense contains some of the most pungent pod types within chiles (Capsicum spp.) (Bosland and Votava, 2000). Pungent cultivars within $C$. chinense typically register 250,000 to 300,000 Scoville heat units (SHU) (Zewdie and Bosland, 2001). No mild C. chinense cultivars are commercially available at this time. 'NuMex Suave Red' and 'NuMex Suave Orange' exhibit very low pungency levels and fill a unique niche in $C$. chinense cultivars.

\section{Origin}

Seed of two accessions that would eventually become 'NuMex Suave Red' and 'NuMex Suave Orange' were initially received into the New Mexico Capsicum Accession Germplasm Repository in 1998 from W.D. Adams, who commented on their mild nature. He received seed, that was referred to as 'Aji Red' and 'Aji Orange', from an anonymous individual. The exact origins of these two accessions are unknown, however, they are phenotypically similar to other known $C$. chinense pod types. 'NuMex Suave Red' is similar to 'Habanero Rojo' and 'NuMex Suave Orange' is similar to 'Yellow Habanero' (DeWitt and Bosland, 1996). Both 'NuMex Suave Orange' and 'Nu-

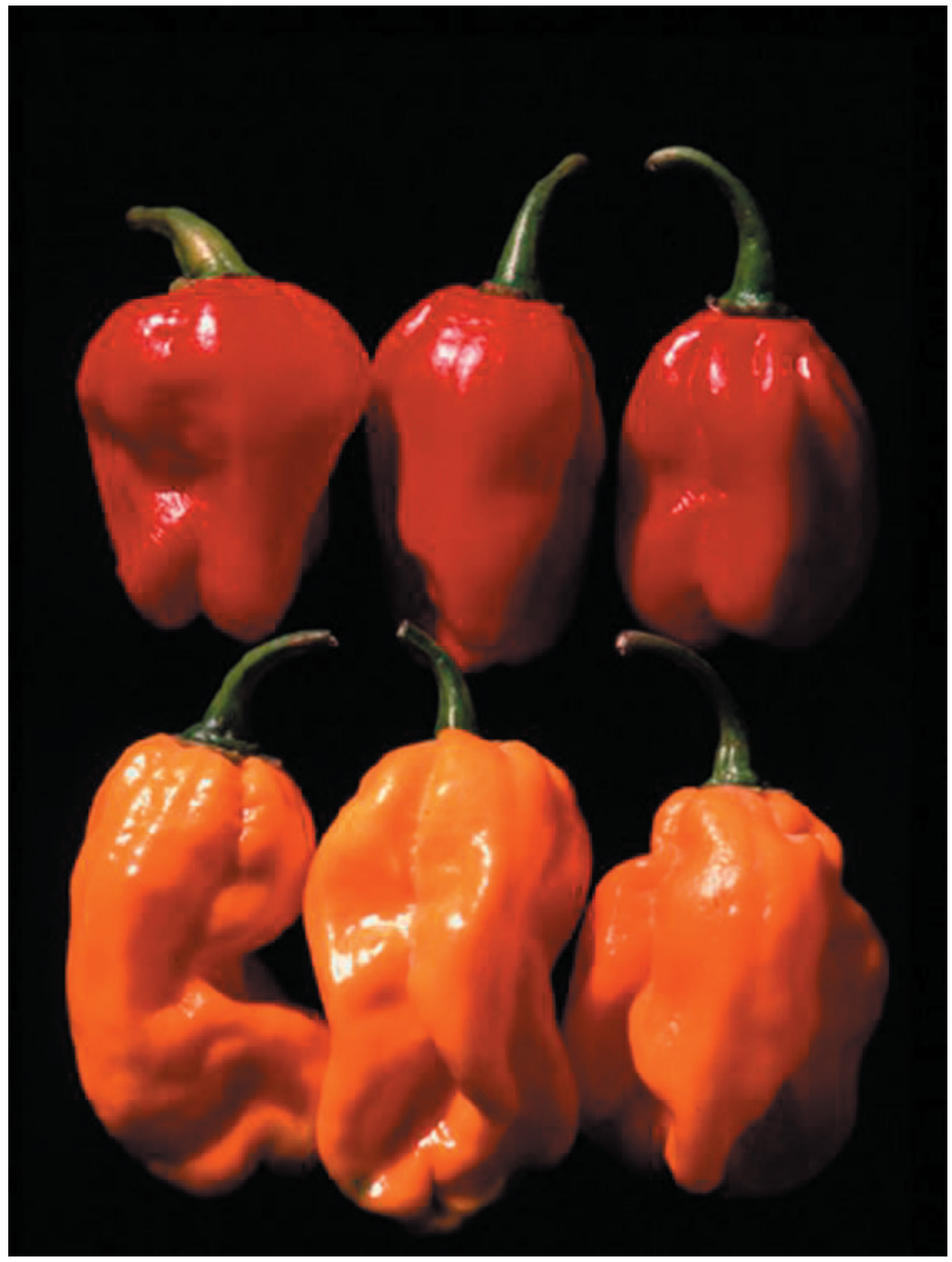

Fig. 1. Mature fruit of (A) 'NuMex Suave Red' and (B) 'NuMex Suave Orange'.

Table 1. Comparison of 'NuMex Suave Red' and 'NuMex Suave Orange' to commercially available 'Habanero'.

\begin{tabular}{|c|c|c|c|c|c|c|c|c|}
\hline \multirow[b]{3}{*}{ Culitvar } & \multicolumn{8}{|c|}{ Characteristic } \\
\hline & \multicolumn{6}{|c|}{ Fruit } & \multicolumn{2}{|c|}{ Plant } \\
\hline & $\begin{array}{l}\text { Mature } \\
\text { color }^{y}\end{array}$ & $\begin{array}{l}\mathrm{Wt}^{\mathrm{z}} \\
(\mathrm{g})\end{array}$ & $\begin{array}{l}\text { Length } \\
(\mathrm{cm})\end{array}$ & $\begin{array}{l}\text { Width } \\
(\mathrm{cm})\end{array}$ & $\begin{array}{c}\text { Wall } \\
\text { thickness } \\
(\mathrm{mm})\end{array}$ & $\begin{array}{l}\text { Pungency } \\
\text { SHU }^{x}\end{array}$ & $\begin{array}{l}\mathrm{Ht} \\
(\mathrm{cm})\end{array}$ & $\begin{array}{l}\text { Width } \\
(\mathrm{cm})\end{array}$ \\
\hline Suave Red & Red 45 A & $9.8 \mathrm{a}^{\mathrm{w}}$ & $4.3 \mathrm{a}$ & $3.1 \mathrm{a}$ & $2.3 \mathrm{a}$ & $774 \mathrm{a}$ & $81 \mathrm{a}$ & $72 a$ \\
\hline Suave Orange & Yellow $23 \mathrm{~A}$ & $8.3 \mathrm{a}$ & $4.4 \mathrm{a}$ & $2.9 \mathrm{ab}$ & $1.9 \mathrm{a}$ & $335 \mathrm{a}$ & $88 \mathrm{a}$ & $76 \mathrm{a}$ \\
\hline Habanerov $^{v}$ & Orange $169 \mathrm{~B}$ & $8.5 \mathrm{a}$ & $4.2 \mathrm{a}$ & $2.6 \mathrm{~b}$ & $2.3 \mathrm{a}$ & $247,475 \mathrm{~b}$ & $52 \mathrm{~b}$ & $71 \mathrm{~b}$ \\
\hline
\end{tabular}

${ }^{2}$ Mean weight of a single fruit.

${ }^{y}$ Color value is reported as the equivalent Royal Horticulture Society color chart standard.

xPungency reported in Scoville heat units.

wMean separation within columns by Duncan's multiple range test at $p<0.05$.

vHabanero seed from Seminis Seed. 
Mex Suave Red' are significantly less pungent than 'Habanero Rojo' and 'Yellow Habanero'. Based on the relatively large size of the fruit and other morphological characteristics, these cultivar releases were undoubtedly derived from a domesticated source and may have originally been local or landrace varieties. Unfortunately those sources remain a mystery, but because of the uniqueness and importance of this material they are being released at this time. These cultivar releases are being designated 'NuMex Suave Red' and 'NuMex Suave Orange' to negate confusion arising from the original 'Aji Red' and 'Aji Orange' because aji is the vernacular name of the species $C$. baccatum L. not $C$. chinense. Additionally, suave means smooth, delicate, or mild in Spanish.

Seed increases of both accessions were made during the field seasons of 1998, 2000, and 2002 at the Leyendecker Plant Science Research Center, Las Cruces, N.M. Replicated field plot trials in a randomized complete-block design with four replications were performed in 2002. 'NuMex Suave Red' and 'NuMex Suave Orange' were compared to each other and to 'Habanero' (Seminis Seeds), which served as the standard control. High-oerformance liquid chromatography (HPLC) measurements of pungency were made in 2001 and 2002.

\section{Description}

'NuMex Suave Red' and 'NuMex Suave Orange' are Capsicum chinense and have pod shapes intermittent between habanero and scotch bonnet. One to three pendant fruit are set at each axil. Basal branching is highly pronounced. Both 'NuMex Suave Red' and 'NuMex Suave Orange' (Fig.1) breed true to type and are assumed to be homogenous for all phenotypic traits.

'NuMex Suave Red' fruit mature from dark green to red (Fig. 1A) and fall within the color red group 45A, according to Royal Horticulture Society (1986) color chart standards. Anthocyanin is entirely absent from stems, leaves, and fruit.

'NuMex Suave Orange' has fruit that mature from a medium green to a yellow-orange (Fig. 1B). Their color is equivalent to yellow group 23A , according to the same chart. Anthocyanin is present on immature green fruit only, disappearing in the mature yelloworange fruit stage.

For 2 years Scoville Heat Unit levels for both cultivars have been $<1000$ SHU based on a dry-weight measurement (Collins et al., 1995). This is $<1 \%$ of standard commercially available 'Habanero'.

Replicated trial comparisons to commercial C. chinense cultivars were undertaken in 2002. Comparisons to a commercially available habanero cultivar, Habanero, (Seminis Seeds) were done (Table 1). There were no differences among 'NuMex Suave Red', 'NuMex Suave Orange', or 'Habanero' for fruit weight, fruit length, or wall thickness. The fruit of 'NuMex Suave Red' were significantly wider than 'Habanero' fruit but not significantly wider than 'NuMex Suave Orange'. 'NuMex Suave
Red' and 'NuMex Suave Orange' were both significantly taller and wider in their plant habits than 'Habanero'. The environment can affect pungency levels, and thus chiles grown in different regions can vary in heat level. Nevertheless, the pungency levels of 'NuMex Suave Red' and 'NuMex Suave Orange' are expected to be significantly less than other habanero cultivars currently available.

\section{Availability}

Limited seed samples will be made available through the Chile Pepper Institute, Las Cruces, N.M. Requests can be made by phone at (505) 646-3028, e-mail at hotchile@nmsu. edu., or mail to CPI, MSC 3Q, NMSU, Las Cruces, NM 88003.

\section{Literature Cited}

Bosland, P.W., and E.J. Votava. 2000. Peppers: Vegetable and spice capsicums. CAB Intl., Wallingford, U.K.

Collins, M.D., L.M. Wasmund, and P.W. Bosland. 1995. Improved method for quantifying capsaicinoids in Capsicum using high-performance liquid chromatography. HortScience 30:137-139.

DeWitt, D. and P.W. Bosland. 1996. Peppers of the world. Ten Speed Press, Berkeley, Calif.

Royal Horticulture Society. 1986. Royal Horticulture Society coulour chart. Royal Hort. Soc., Grower Council Holland, Leiden, Netherlands.

Zewdie, Y. and P.W. Bosland. 2001. Capsaicinoid profiles are not good chemotaxonomic indicators for Capsicum species. Biochem. Syst. Ecol. 29:161-169. 